\title{
Heterologous expression of the clostripain gene from Clostridium histolyticum in Escherichia coli and Bacillus subtilis: maturation of the clostripain precursor is coupled with self-activation
}

\author{
Volker Witte, Norbert Wolf, Thomas Diefenthal, Gernot Reipen and \\ Harald Dargatz
}

Author for correspondence: Harald Dargatz. Tel: +492632400273 . Fax: +492632400241.

Weissheimer Research Laboratory, Schaarstrasse 1, D-56626 Andernach, Germany

\begin{abstract}
Clostripain-specific antibodies were used to analyse the maturation of clostripain prepro-enzyme and core protein heterologously synthesized in Escherichia coli and Bacillus subtilis. Core protein purified from E. coli cells harbouring plasmid pHM3-23 underwent calcium-dependent, self-triggered maturation. Concomitantly, the inactive form of the enzyme was converted into an active form, demonstrating the self-activation capacity of the clostripain core protein. As judged from Western blot analysis, the major portion of the protein in E. coli was degraded, presumably by the activated clostripain. The enzyme was not exported to the $E$. coli periplasm, either by use of the putative Clostridium histolyticum signal peptide or by use of the E.coli OmpA signal peptide. Therefore, the Gram-positive micro-organism B. subtilis was chosen as an alternative host for the expression of the prepro-enzyme and the core protein. BR 151 cells harbouring PHM7-10B secreted clostripain precursor to the growth medium and matured subsequently to the active enzyme. As only a small amount of activity was detected intracellularly, the putative $C$. histolyticum signal peptide was efficiently recognized by the B.subtilis secretion apparatus. Under optimized conditions, a level of $4500 \mathrm{U} \mathrm{I}^{-1}$ could be obtained in batch cultures.
\end{abstract}

Keywords: Clostridium bistolyticum, clostripain, protein processing, heterologous expression, self-activation (autocatalysis)

\section{INTRODUCTION}

Amongst endopeptidases, the cysteine proteinase clostripain (EC 3.4.22.8) exhibits several remarkable features. Native clostripain recovered from the culture filtrate of Clostridium bistolyticum strains (Kocholaty, 1938) is composed of two polypeptide chains, with molecular masses of $41.7 \mathrm{kDa}$ and $15.4 \mathrm{kDa}$ for the heavy and the light chain, respectively (Gilles et al., 1979). By application of radiolabelled inhibitors, $\mathrm{Cys}^{41}$ of the heavy chain was identified as the catalytic amino acid residue of the active site (Gilles et al., 1983). N- $\alpha$-p-tosyl-L-lysine chloromethyl ketone (TLCK) specifically inactivates $\alpha$-clostripain by reacting with the sulfhydryl group of the active site cysteinyl residue whilst another inhibitor of cysteine

Abbreviation: TLCK, $N$ - $\alpha$-p-tosyl-L-lysine chloromethyl ketone. proteases, E-64, failed to inhibit clostripain activity (Gilles \& Keil, 1984). Amino acid sequences surrounding the active site cysteinyl residue do not bear any resemblance to active site sequences of other known cysteine proteinases (Gilles et al., 1983) or serine proteinases (Dargatz et al., 1993).

Clostripain is well-known for its highly restricted substrate specificity for Arg-Xaa peptide bonds (Ogle \& Tytell, 1953). Therefore, clostripain has attracted interest for protein sequencing purposes and as a catalyst for condensation of pharmaceutically important peptides containing Arg-Pro bonds which are not readily synthesized by chemical means (Fortier \& McKenzie, 1986a, b; Meiwes et al., 1991). For broader biotechnical application, it is desirable to obtain clostripain preparations in high yields from recombinant strains which offer the advantage of being free of contaminating clostridial toxins. 
Following this aim, the $C$. bistolyticum gene encoding clostripain has recently been cloned and analysed (Dargatz et al., 1993). The newly synthesized precursor protein consists of a putative signal peptide (27aa), pro-peptide (23aa), light chain subunit (131aa), linker peptide (9aa) and heavy chain subunit (336aa). Heterologous expression experiments utilizing a modified gene lacking the signal and pro-peptide demonstrated that the $\mathrm{N}$-terminal 50 amino acid residues of the clostripain precursor were dispensable for obtaining proteolytic activity in E. coli (Dargatz et al., 1993).

From the amino acid sequence it was suggested that processing of the native clostripain precursor involves the removal of the internal nonapeptide linker joining the two chains of the clostripain in the precursor. This linker peptide is preceded by an arginyl residue $\left(\mathrm{Arg}^{181}\right)$ and also ends with an arginyl residue ( $\left.\operatorname{Arg}^{190}\right)$. In the light of the specificity of the enzyme for arginyl residues this could provide an ideal basis for autocatalytic processing. There is evidence that many secreted bacterial proteases are capable of autodigestion to gain their fully processed structure (Wandersman, 1989; Silen et al., 1989; Terada et al., 1990; Ohta et al., 1991). During clostripain maturation the activity of the clostripain core protein (light chain, linker, heavy chain) may suffice to promote the processing to the heterodimer, which thereby becomes endowed with increased hydrolytic activity (self-activation).

So far, enzymically active clostripain has been produced at low levels in E. coli and maturation to heterodimers could not be demonstrated unambiguously (Dargatz et al., 1993) due to the lack of clostripain-specific antibodies. In this paper we demonstrate that only a minor amount of clostripain precursor synthesized in the E. coli cytoplasm is processed to form the mature and active enzyme. In contrast, expression in the Gram-positive host $B$. subtilis yielded high amounts of active protease secreted to the growth medium.

\section{METHODS}

Molecular cloning procedures and plasmid constructions. Most of the methods used for molecular cloning are described by Sambrook et al. (1989) and Hardy (1988). E. coli strain XL1Blue (recA1 lac endA1 gyrA96 thi bsdR17 supE44 relA1 $F^{\prime}$ pro $A B$ lacI ${ }^{2} Z \Delta M 15 \operatorname{Tn} 10$ ) (Bullock et al., 1987) and B. subtilis strain BR151 (trpC2 metB10 lys-3) (ATCC 33677) were used as plasmid hosts. Plasmids pFLAG-1 (Hopp et al., 1988) and pDS56RBSII-2 (Stueber et al., 1984) were used as vectors for clostripain expression in E. coli. The E. coli/B. subtilis shuttle vector pREP9 (LeGrice, 1990) was used for clostripain expression in B. subtilis. Competent B. subtilis cells were prepared according to Dubnau \& Davidoff-Abelsen (1971). For transformation of $B$. subtilis cells, plasmid DNA was linearized by $K p n \mathrm{I}$ digestion and the resulting DNA fragments were oligomerized by T4 DNA ligase treatment (Canosi et al., 1978). Transformants were initially selected on LB agar plates containing kanamycin as the only antibiotic agent. Since head-tohead ligation of linearized plasmid DNA and recombination events may impede the recovery of proper transformants, replica plating onto LB agar plates containing chloramphenicol and $0.1 \mathrm{mM}$ IPTG served to identify the desired clones.

For construction of plasmid $\mathrm{p} 2-\mathrm{O}$, we employed the following oligonucleotide primers: 5' CGCATGCCTAGGGTTAACCAGTAACTAAATCCAAGGAT $3^{\prime}$ (5' primer) and $5^{\prime}$ TTGTCGACTCCCGGGTTACCATTGGTAATGATTAACTCCTCC $3^{\prime}$ ( $3^{\prime}$ primer). The desired part of the clostripain coding region was amplified by PCR. The generated DNA fragment was digested with $A v r \mathrm{II}$ and $S a l \mathrm{I}$ prior to ligation into $\mathrm{XbaI}$ and XboI-digested pFLAG-1. The construction of plasmids pHM323 and pHM7-10 has been described previously (Dargatz et al., 1993). For construction of pHM3-23B and pHM7-10B, the vector $\mathrm{pREP} 9$ was employed. The expression cassette of $\mathrm{pREP9}$ was removed by $\mathrm{XhoI} / \mathrm{SalI}$ double digestion and substituted by XhoI/SalI DNA fragments bearing the compatible expression cassettes of pHM3-23 and pHM7-10, respectively. Thus, cat gene function was restored in the resulting plasmids $\mathrm{pHM} 3-23 \mathrm{~B}$ and pHM7-10B. XL1-Blue transformants grown on chloramphenicol-containing medium immediately allowed the isolation of plasmids bearing the desired expression cassettes in proper orientation.

Analysis of heterologous expression in E. coli. E. coli XL1Blue transformants were cultivated overnight at $37^{\circ} \mathrm{C}$ in $\mathrm{LB}$ medium supplemented with the appropriate antibiotics. For induction of clostripain synthesis, cultures grown to an $\mathrm{OD}_{600}$ of about 0.4 were adjusted to a final concentration of $1 \mathrm{mM}$ IPTG and cultivation was continued for $3 \mathrm{~h}$. Cells were harvested by centrifugation and periplasmic fractions were prepared by the cold osmotic shock procedure (Neu \& Heppel, 1965). For subsequent release of cytoplasmic proteins, the resulting pellet was resuspended in lysis buffer $[10 \mathrm{mM}$ $\mathrm{Na}_{2} \mathrm{HPO}_{4}, \mathrm{pH} 7 \cdot 0,30 \mathrm{mM} \mathrm{NaCl}, 0.25 \%$ (v/v) Tween 20, $1 \mathrm{mM}$ EDTA]. Cell disruption was achieved by repeated sonification on ice using a Bandelin Sonopuls HD70 sonicator at $70 \%$ power. After centrifugation at $20000 \mathrm{~g}$ for $20 \mathrm{~min}$ the cytoplasmic fraction of soluble proteins was obtained in the supernatant. For SDS-PAGE and/or Western blot analysis, the insoluble material was directly resuspended in SDS-sample buffer and boiled for $5 \mathrm{~min}$. Pellet samples to be checked for clostripain activity were either solubilized in $4 \mathrm{M}$ urea solution buffered with $40 \mathrm{mM}$ Tris/acetate, $\mathrm{pH} 8.5$, or in $1 \%(\mathrm{w} / \mathrm{v})$ SDS solution. From the latter, the detergent was removed by conventional buffer exchange procedures prior to the clostripain assay. As clostripain retains its full enzymic activity in the presence of $4 \mathrm{M}$ urea (Lowe et al., 1987), samples treated this way were used directly for enzyme activity measurements.

Determination of clostripain activity. Prior to assay, $0 \cdot 1$ vols of 10 -fold concentrated activation buffer $(500 \mathrm{mM}$ Tris $/ \mathrm{HCl}$ $\mathrm{pH} 7 \cdot 0,50 \mathrm{mM}$ DTT) were added to aliquots of the enzyme preparation. Activity determinations were carried out at room temperature in assay buffer $(50 \mathrm{mM}$ Tris $/ \mathrm{HCl}, \mathrm{pH} 7 \cdot 5$, $5 \mathrm{mM} \mathrm{DTT}, 2 \mathrm{mM} \mathrm{CaCl}$ ) containing $N$-carbobenzoxy-Larginine $p$-nitroanilide ( $\mathrm{Z}-\mathrm{Arg}$-pNA) at a concentration of $260 \mu \mathrm{M}$. The release of $p$-nitroaniline was followed spectrophotometrically measuring the absorbance increase at $410 \mathrm{~nm}$. Enzyme activities were calculated using a molar extinction coefficient of $\varepsilon_{\mathbf{4 1 0}}=5570 \mathrm{M}^{-1} \mathrm{~cm}^{-1}$. For determination of specific enzyme activities [ $\mathrm{U}(\mathrm{mg} \text { protein })^{-1}$ ], the protein concentration was measured by the method of Bradford (1976) using bovine $\gamma$-globulin as a standard.

For specific inhibition of clostripain activity or inhibition of maturation of clostripain precursors, TLCK dissolved in $1 \mathrm{mM} \mathrm{HCl}, \mathrm{pH} 3 \cdot 2$, was used at concentrations between $10 \mu \mathrm{M}$ and $200 \mu \mathrm{M}$.

Purification of clostripain core protein from E. coli. XL1-Blue cells transformed with pHM3-23 were cultivated in a 51 fermenter under induced conditions (see above) for $4 \mathrm{~h}$ and harvested by centrifugation. Cells were washed once in $20 \%$ $(\mathrm{w} / \mathrm{v}$ ) sucrose, $30 \mathrm{mM}$ Tris $/ \mathrm{HCl}, \mathrm{pH} 8 \cdot 0,1 \mathrm{mM}$ EDTA, dis- 
rupted by sonification and centrifuged again. The resultant pellet was solubilized in $50 \mathrm{ml}$ of $4 \mathrm{M}$ urea, $40 \mathrm{mM}$ Tris/acetate, $\mathrm{pH} 8.5$. After renewed centrifugation the supernatant was desalted at $4{ }^{\circ} \mathrm{C}$ on a $\mathrm{G} 25 \mathrm{M}$ Sephadex column $(5 \times 50 \mathrm{~cm}$, flow rate $7.5 \mathrm{ml} \mathrm{min}{ }^{-1}$ ) equilibrated with $20 \mathrm{mM}$ Tris $/ \mathrm{HCl}, \mathrm{pH} 7 \cdot 5$, and subjected to ion exchange chromatography on a Sepharose $Q$ column $\left(2.6 \times 10 \mathrm{~cm}\right.$, flow rate $\left.2.5 \mathrm{ml} \mathrm{min}^{-1}\right)$ equilibrated with the same buffer. Bound protease was eluted at $0.56 \mathrm{M} \mathrm{NaCl}$. The enzyme solution was adjusted to $4 \mathrm{M}$ urea, concentrated in an Amicon ultrafiltration apparatus using a YM-30 membrane and subsequently kept at $-20{ }^{\circ} \mathrm{C}$ without loss of activity.

Maturation analysis of clostripain core protein. For activation/maturation studies, $150 \mu \mathrm{l}$ of a $4 \mathrm{M}$ urea solution containing $315 \mu \mathrm{g}$ purified clostripain core protein (see above) were supplied with $17 \mu$ of $10 \times$ activation buffer and incubated at room temperature. Samples $(6 \mu \mathrm{l})$ were taken at different time points and immediately boiled in sample buffer for analysis by Western blotting. A second $6 \mu$ sample was immediately assayed for clostripain activity. Calculations of the respective enzyme activities were exclusively based on the increases in absorbance observed during the first minute after addition of the enzyme to the assay solution.

Analysis of heterologous expression in B. subtilis. B. subtilis BR151 transformants were cultured with vigorous agitation in LB medium containing $10 \mu \mathrm{g}$ kanamycin $\mathrm{ml}^{-1}$ and $50 \mu \mathrm{g}$ chloramphenicol $\mathrm{ml}^{-1}$. As cat gene function is dependent on the transcription of the expression cassette, IPTG was added to yield a final concentration of $0 \cdot 1 \mathrm{mM}$ to ensure a minimum of CAT protein synthesis. For high-level protein synthesis, diluted cultures were grown for $4 \mathrm{~h}$ at $30^{\circ} \mathrm{C}$ and transferred to excess $5 Y C$ medium (Yamagata et al., 1989) supplemented with kanamycin and chloramphenicol at concentrations as stated above. At the same time, the IPTG concentration was raised to $2 \mathrm{mM}$ and cultivation was continued at $37^{\circ} \mathrm{C}$ for several hours. For analysis of the supernatant, cells were removed by centrifugation, washed with sterile water to remove adherent proteins and finally resuspended in activation buffer. Crude extracts were obtained by lysozyme treatment, and subsequent lysis of spheroplasts was achieved by addition of SDS to a final concentration of $0 \cdot 1 \%(\mathrm{w} / \mathrm{v})$. As clostripain activity is not affected by SDS concentrations lower than $0.01 \%$, samples of these homogenates diluted 20 -fold were used for activity determinations.

PAGE and Western blot analysis. SDS-PAGE according to Laemmli (1970) was carried out as described by Studier (1973). Diluted protein samples were concentrated by precipitation with $5 \%(\mathrm{v} / \mathrm{v})$ TCA on ice for $30 \mathrm{~min}$. For Western blot analysis, proteins were transferred according to Towbin et al. (1979) to nylon membranes, employing the semi-dry blotting procedure (Kyhse-Anderson, 1984). Clostripain-specific antibodies (anti-Clos) were prepared by the Serum Institute, Copenhagen, Denmark, using native clostripain (Sigma, catalogue no. C7403) as antigen. For immunodetection, anti-Clos was used as primary antibody, and anti-rabbit IgG conjugated to peroxidase was used as secondary antibody. Immunoreactive proteins were visualized employing 3-amino-9-ethylcarbazole as peroxidase substrate.

\section{RESULTS}

\section{Clostripain expression in $E$. coli}

Expression of clostripain sequences in E. coli was investigated using previously described constructs pHM7-10 and pHM3-23 (Fig. 1; Dargatz et al., 1993) encoding prepro-enzyme and core protein, respectively. Crude extracts from the respective XL1-Blue transformants were fractionated and subsequently assayed for clostripain activity and analysed by SDS-PAGE and Western blot experiments. Since the antibodies raised against native clostripain failed to recognize the clostripain light chain subunit on Western blots (cf. Fig. 3a), clostripain processing events had to be followed immunoenzymically by the appearance of antigenic heavy chain molecules.

As expected, no clostripain activity was found in the periplasm of cells harbouring pHM3-23 (Table 1), which does not provide a signal peptide for protein secretion. From transformants carrying pHM7-10, it was impossible to obtain periplasmic fractions, since cells lysed upon resuspension in washing buffer $[20 \%(\mathrm{w} / \mathrm{v})$ sucrose, $10 \mathrm{mM}$ Tris/HCl, pH 7·6, $1 \mathrm{mM}$ EDTA]. Neither clostripain activity nor proteinaceous material reacting with clostripain-specific antibodies were detected in the fraction containing both periplasmic and cytoplasmic proteins (Table 1, Fig. $2 \mathrm{~b}$ lane 1). Therefore, a third plasmid, p2-O (Fig. 1) was constructed, which would allow for the export of clostripain to the periplasmic space of $E$. coli utilizing the OmpA signal sequence. However, no clostripain activity could be detected in the periplasm of the resulting transformants (Table 1), indicating that translocation of clostripain precursors is impeded in $E$. coli probably due to protein aggregation effects.

In the soluble fractions representing intracellular proteins from XL1-Blue transformants carrying pHM7-10, p2-O and pHM3-23, no, or only minimal enzyme activity could be found (Table 1). Most of the clostripain activity was found in the pellet fraction resulting from crude extract preparations upon solubilization with $4 \mathrm{M}$ urea or $1 \%$ (w/v) SDS (Table 1). These results were confirmed by SDS-PAGE and Western blot experiments (Fig. 2). Clostripain precursors could be identified with the clostripain-specific antiserum instead of the previously employed differences in electrophoretic behaviour (Dargatz et al., 1993). The antibodies proved to be clostripainspecific, as endogenous $E$. coli proteins (Fig. 2a) did not cross-react in Western blot analysis (Fig. 2b).

Immunochemically detectable protease material was only found in fractions of insoluble proteins (Fig. 2b, lanes 2, 5 and 8 ). The appearance of antigenic proteins in the range of $53-61 \mathrm{kDa}$ and the absence of any antigenic protein comigrating with the heavy chain subunit of clostripain demonstrates that the synthesized enzyme remains in an unprocessed form in $E$. coli. This agrees well with the observation of a lag phase (10-20 min) during the enzymic assays which reflects an in vitro activation process.

Clostripain core protein purified from pHM3-23 E. coli transformants was assayed for its in vitro maturation capacity. For this purpose the core enzyme was incubated in a DTT- and $\mathrm{Ca}^{2+}$-containing buffer to initiate an activation/maturation process. Samples were taken at different time points to follow changes in the enzymic activity as well as electrophoretic mobility of the clostripain molecule (Fig. 3). 


\begin{tabular}{|c|c|c|c|}
\hline Vector & Promoter & Signal & Expressio \\
\hline pDS56RBSII-2 & $\mathrm{P}_{\mathrm{N} 25} / \mathrm{LacO}$ & Clos & pHM?-10 \\
\hline pDS56RBSII-2 & $\mathrm{P}_{\mathrm{N} 25} / \mathrm{LacO}$ & - & pHM3-23 \\
\hline pFLAG-1 & Tac & OmpA & $\mathrm{p} 2-0$ \\
\hline pREP9 & $\mathrm{P}_{\mathrm{N} 25} / \mathrm{LacO}$ & Clos & pHM7-10B \\
\hline pREP9 & $P_{\mathrm{N} 25} / \mathrm{LacO}$ & - & pHM3-23B \\
\hline
\end{tabular}

Fig. 1. Characteristic features of clostripain expression constructs. The host for constructs pHM7-10, pHM3-23 and p2-O was $E$. coli, and $B$. subtilis for pHM7-10B and pHM3-23B. Characteristic elements of the entire clostripain precursor protein ( $526 \mathrm{aa}$ ) are indicated as follows: putative clostripain signal peptide Clos (stippled box), clostripain pro-peptide (hatched box), light chain-subunit domain (LC), linker peptide (black box) and heavy chain-subunit domain (HC). In construct p2-O, signal peptide OmpA derived from $E$. coli outer-membrane protein is represented by a grey box and the adjacent FLAG-octapeptide is symbolized by a flag. Extra $\mathrm{N}$-terminal amino acid residues derived from vector sequences as well as the respective first amino acids encoded by the clostripain gene are given in the one-letter code. Stop codons (TAA) are indicated by asterisks. Calculated molecular masses for LC- and HC-subunits are given at the top of the figure.

\section{Table 1. Clostripain activity in $E$. coli transformants}

Values given in this table are the mean from four different measurements and were obtained from IPTG-induced 0.51 cultures. None of the corresponding non-recombinant control transformants showed clostripain activity.

\begin{tabular}{|c|c|c|c|}
\hline \multirow[t]{3}{*}{ Plasmid } & \multicolumn{3}{|c|}{ Activity [U (g cells $\left.)^{-1}\right]$} \\
\hline & \multicolumn{2}{|c|}{ Soluble fraction } & \multirow{2}{*}{$\begin{array}{l}\text { Insoluble } \\
\text { fraction* }\end{array}$} \\
\hline & Periplasm & Cytoplasm & \\
\hline pHM7-10 & \multicolumn{2}{|c|}{$0+$} & $17 \cdot 8$ \\
\hline $\mathrm{p} 2-\mathrm{O}$ & 0 & $0 \cdot 6$ & $30 \cdot 2$ \\
\hline pHM3-23 & 0 & $8 \cdot 5$ & $32 \cdot 9$ \\
\hline
\end{tabular}

* Insoluble matter (obtained during conventional crude extract preparation) solubilized in $4 \mathrm{M}$ urea (see Methods).

†Periplasm + cytoplasm (see text).

After $10 \mathrm{~min}$ of incubation the appearance of clostripain activity was observed $\left(1.4 \mathrm{mU}_{\mu \mathrm{g}}{ }^{-1}\right)$, steadily increasing during further activation. After $1 \mathrm{~h}$, the enzyme activity reached a level of $7 \cdot 2 \mathrm{mU}^{\prime} \mathrm{g}^{-1}$ and remained unchanged for at least 2 further hours (Fig. 3b). The acquisition of enzymic activity was paralleled by a shift in the protein band patterns as judged from Western blot analysis (Fig. 3a, lanes 1-3 vs. lanes 7 and 8). Both the decrease of antigenic material representing the core enzyme as well as the correlated increase of antigenic protein comigrating with the clostripain heavy chain subunit at the time the enzyme is gaining detectable activity (Fig. 3a, lane 4) indicate, that the core protease is capable of processing and activating itself to mature clostripain. This interpretation is strengthened by the fact that maturation of the core protease is abolished in the presence of specific (a)

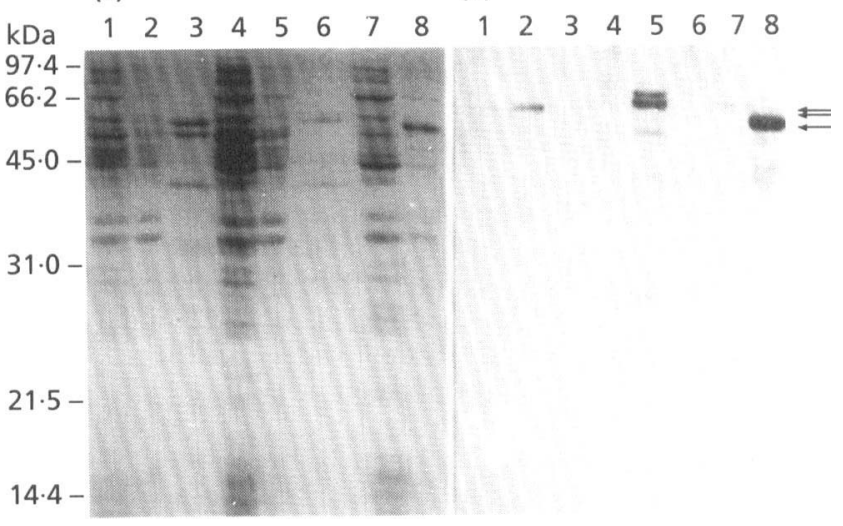

Fig. 2. Localization of heterologously expressed clostripain in $E$. coli. Crude extract fractions were prepared from $E$. coli XL1Blue transformants carrying plasmids pHM7-10 (lanes 1 and 2), p2-O (lanes 3-5) and pHM3-23 (lanes 6-8). Protein samples of each fraction were separated by SDS-PAGE ( $15 \%$ acrylamide) and either stained directly with Coomassie brilliant blue (a) or electrotransferred to nylon membrane for Western blot analysis using clostripain-specific antibodies (b). Lanes: 1, periplasmic and cytoplasmic proteins (see text); 2,5 and 8 , insoluble proteins; 3 and 6 , periplasmic proteins; 4 and 7 , cytoplasmic proteins. Clostripain precursors are indicated by arrows.

inhibitors of clostripain activity, namely TLCK and leupeptin (data not shown).

However, as can be deduced from the band intensities (Fig. 3a, lanes 1 and 8), only a minor portion of the core protein was converted to the correctly processed form. As soon as maturation was initiated, an additional collection of immunoreactive proteins with molecular masses lower than that of the clostripain heavy chain appeared (Fig. 3a, lanes 4 and 5). Upon prolonged incubation, the additional protein bands disappeared again (Fig. 3a, lanes 5-8). The transiently appearing protein bands can all be explained as partial hydrolysis products derived from specific cleavage 
(a)

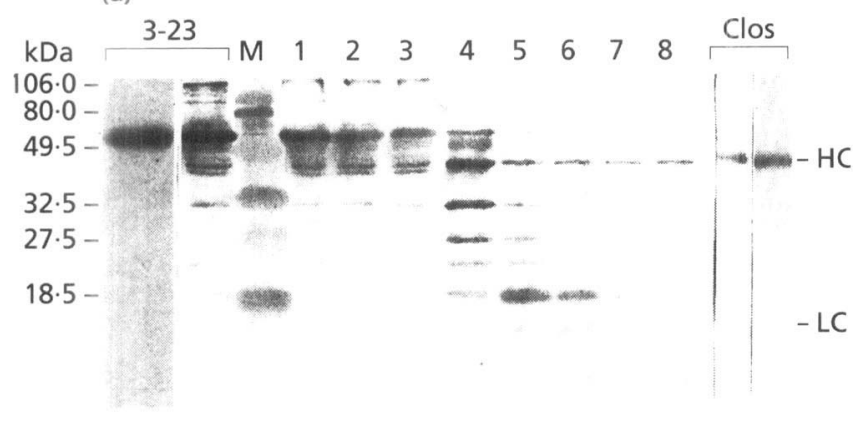

(b)

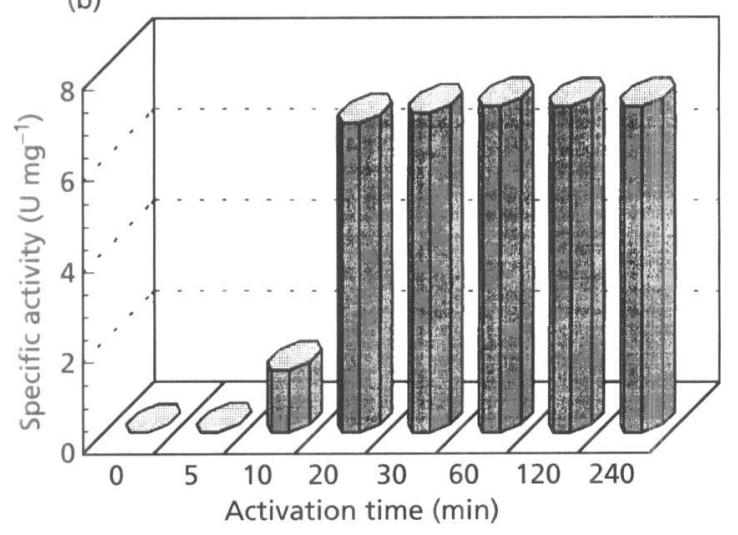

Fig. 3. In vitro processing of purified clostripain core protein. (a) Samples $(11.25 \mu \mathrm{g}$ protein) of purified clostripain core enzyme were separated by SDS-PAGE ( $15 \%$ acrylamide) and subjected to Western blot analysis after activation (see Methods) for 0 (lane 1), 5 (lane 2), 10 (lane 3), 20 (lane 4), 30 (lane 5), 60 (lane 6), 120 (lane 7) and $240 \mathrm{~min}$ (lane 8). Purified core enzyme without the addition of activation buffer (3-23) and native clostripain (Clos) were co-analysed immunochemically or directly detected in the gel by Coomassie brilliant blue staining (flanking lanes 3-23 and Clos). Banding positions of clostripain heavy and light chain-subunits are indicated by $\mathrm{HC}$ and $\mathrm{LC}$, respectively. $M$, prestained molecular mass markers. (b) The specific clostripain activities of the analysed samples (1-8) are represented by columns.

reactions occurring at some of the arginine residues located in the clostripain core molecule. This supports the assumption, that the observed degradation affecting the major portion of the enzyme most probably is attributed to the action of mature clostripain.

\section{Clostripain expression in B. subtilis}

Plasmids pHM3-23 and pHM7-10 offer the advantage that their expression cassettes are compatible with the B. subtilis transcription machinery (Peschke et al., 1985). Utilizing the E. coli/B. subtilis shuttle vector $\mathrm{pREP9}$ (LeGrice, 1990), plasmids pHM3-23B and pHM7-10B were generated (Fig. 1). B. subtilis transformants were assayed for clostripain activity. As expected, no clostripain activity was detected in supernatants from transformants harbouring pHM3-23B (Table 2), as no signal peptide is provided in this construct (Fig. 1). In contrast to this, BR
Table 2. Clostripain activity in B. subtilis transformants

Representative values given in this table were obtained from $25 \mathrm{ml}$ cultures grown for $1 \mathrm{~h}$ (I) and $22 \mathrm{~h}$ (II), respectively, under conditions for high level protein synthesis (see Methods). None of the corresponding non-recombinant control transformants showed clostripain activity.

\begin{tabular}{|c|c|c|c|c|}
\hline \multirow[t]{3}{*}{ Plasmid } & \multicolumn{4}{|c|}{ Activity $\left[\mathrm{U}(\mathrm{g} \text { cells })^{-1}\right]$} \\
\hline & \multicolumn{2}{|c|}{ Cytoplasm } & \multicolumn{2}{|c|}{ Medium } \\
\hline & I & II & I & II \\
\hline pHM7-10B & $0 \cdot 1$ & 0 & 20 & 395 \\
\hline pHM3-23B & $0 \cdot 1$ & 0 & 0 & 0 \\
\hline
\end{tabular}

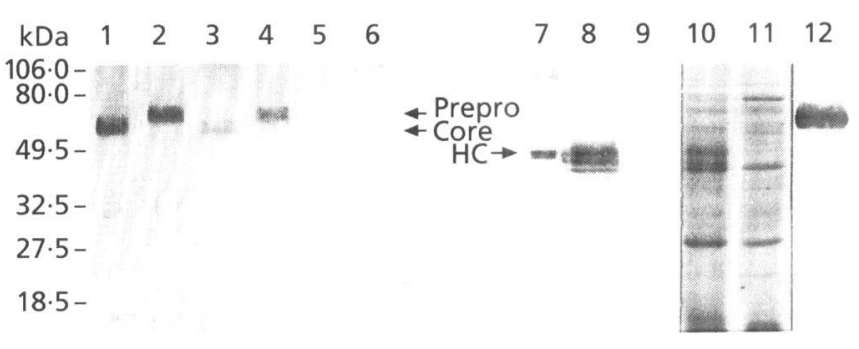

Fig. 4. Analysis of heterologous clostripain expression in B. subtilis. Crude extract proteins from BR 151 transformants were separated by SDS-PAGE ( $12 \%$ acrylamide) and subjected to Western blot analysis (lanes 1-6). Lanes 1, 3 and 5, pHM3-23B; lanes 2, 4 and 6, pHM7-10B. Crude extracts from cells cultured under IPTG-induced conditions were prepared after growing for 1 (lanes 1 and 2), 3 (lanes 3 and 4) and $22 \mathrm{~h}$ (lanes 5 and 6). Immunosignals representing the putative clostripain precursors (prepro and core) are indicated by arrows. Supernatants from $B$. subtilis cells cultured under IPTG-induced conditions for $6 \mathrm{~h}$ (lanes 7-11) or for $3 \mathrm{~h}$ in the presence of TLCK (lane 12) were electrophoresed as described and stained directly with Coomassie brilliant blue (lanes 10 and 11) or were analysed by Western blotting (lanes 7-9 and 12). Lanes 8, 10 and 12, pHM710B; lanes 9 and 11, pHM3-23B. In lane 7, an immunoblot of native clostripain is shown as a control for the banding position of the heavy chain $(\mathrm{HC})$. In lane 12, supernatant was concentrated 20 -fold by TCA precipitation.

151 cells harbouring pHM7-10B secreted active clostripain to the growth medium (Table 2), indicating that the C. bistolyticum signal peptide is recognized by the B. subtilis secretion apparatus. Typically, clostripain activity was detectable after $1 \mathrm{~h}$ of induction $\left(40 \mathrm{U} \mathrm{l}^{-1}\right)$. Within the next $2 \mathrm{~h}$ of cultivation, clostripain activity increased to $800 \mathrm{U} \mathrm{l}^{-1}$ and reached a value of $4500 \mathrm{U} \mathrm{l}^{-1}$ upon further cultivation for $22 \mathrm{~h}$.

Only weak intracellular activity was measured. Homogenates prepared from cells after $1 \mathrm{~h}$ of induction exhibited only minimal clostripain activity (Table 2). In homogenates of cells which had been cultivated for $22 \mathrm{~h}$, no clostripain activity could be found (Table 2). Samples of these homogenates were subjected to Western blot analysis (Fig. 4). In crude extracts of BR151 cells containing either pHM3-23B or pHM7-10B, antigenic 
material of higher molecular mass than that of the clostripain heavy chain was detected with clostripainspecific antibodies (Fig. 4, lanes 1 and 2), suggesting that clostripain precursors are synthesized upon IPTG induction. Continuing the fermentation, the amount of antigen diminished as judged by the decrease of band intensities (Fig. 4, lanes 3, 4, 5 and 6).

In culture supernatants of BR151 transformants harbouring pHM7-10B, antigenic proteins were detected, the largest one (Fig. 4, lane 8) comigrating with the heavy chain of native clostripain (Fig. 4, lane 7). This protein was visible in polyacrylamide gels upon Coomassic brilliant blue staining (Fig. 4, lane 10), corresponding to the high clostripain activity found in the supernatants. In contrast to expression in E. coli, there was no activation step required to detect this antigen by immunoblot analysis and no lag phase was observed during activity measurements (data not shown). In the presence of specific inhibitors of clostripain activity, namely TLCK, an antigenic protein with a molecular mass corresponding to that of the clostripain pro-enzyme can be detected in Western blots (Fig. 4, lane 12). Taken together, these results indicate that a clostripain precursor is secreted to the extracellular side of the bacterial cytoplasmic membrane. As neither induced BR151 cells carrying pREP9 nor culture supernatant derived thereof provoke maturation of purified core peptide synthesized in E. coli (data not shown), we suggest that the clostripain precursor secreted by BR151 transformants carrying pHM7-10B is auto-matured to yield the active clostripain heterodimer. Proteolytic degradation by action of other extracellular endopeptidases (Wu et al., 1991) seems to occur since additional immunobands of greater mobility than that of the heavy chain were formed (Fig. 4, lane 8).

\section{DISCUSSION}

We have studied the maturation of the clostripain core protein synthesized in the heterologous host E. coli. The main portion of the clostripain precursor synthesized in E. coli was insoluble and required urea or SDS to effect its solubilization. Purified clostripain precursor was inactive, but in the presence of calcium ions it matured in vitro under conditions which minimize oxidation. As we did not find arginyl-specific endopeptidase activity in E. coli (Dargatz et al., 1993), the observed maturation must be due to an intrinsic property of the clostripain precursor. This is consistent with the fact that the nonapeptide linker is preceded by an arginyl residue $\left(\mathrm{Arg}^{181}\right)$ and also ends with such a residue $\left(\operatorname{Arg}^{190}\right)$, which provide an ideal substrate for autocatalytic processing by this arginylspecific protease (Dargatz et al., 1993).

Maturation of the clostripain core protein was accompanied by an increase in enzymic activity. Application of the specific clostripain inhibitors TLCK and leupeptin, or omission of calcium ions, prevented self-activation, whereas the omission of DTT caused a reduced final activity presumably due to a deceleration of the maturation process (data not shown). Therefore, we suggest that clostripain maturation is calcium-dependent, but essentially self-triggered by intrinsic properties of the precursor molecule.

There have been many other reports on proteases with self-processing properties (bacterial enzymes have been reviewed by Wandersman et al., 1989). The best studied protease in this regard is probably subtilisin. Here, a Nterminal pro-peptide plays a crucial role in folding of the immature precursor before it is cleaved off (Ohta et al., 1991). In other proteases of bacterial origin, C-terminal extensions are removed before the active enzyme is generated (Ohara et al., 1989; Terada et al., 1990).

The situation is different for clostripain maturation. Since expression constructs containing the pro-peptide sequence exhibit a clostripain activity similar to constructs lacking this sequence (Table 1 and unpublished data), maturation of the clostripain precursor synthesized in $E$. coli does not depend on the 23 amino acid residue propeptide. However, its precise function remains unclear, but is under investigation. Pro-peptides of similar length are often seen in other proteins originating from Bacillus species. No specific function could be demonstrated for these pro-peptides, but upon secretion they can be removed by other proteases (Simonen \& Palva, 1993).

A dispensable C-terminal region was not found in the clostripain prepro-enzyme. Instead, sensitivity of the maturation process towards alterations at the ultimate $C$ terminus of the precursor was observed. In heterologous expression experiments, C-terminal deletions comprising merely 20 amino acid residues resulted in complete loss of activity (data not shown).

The removal of the internal linker nonapeptide is the most striking feature of the clostripain maturation pathway. A similar case has been reported for penicillin $G$ acylase from $E$. coli, which is synthesized as a pre-enzyme and maturated to a heterodimer by a multistep processing including the removal of an internal 54 amino acid residue peptide (Sizmann et al., 1990). The triggering protease has not yet been identified, but an autocatalytic maturation by hidden intrinsic properties of the penicillin acylase precursor was shown to be unlikely. Thus, to our present knowledge the removal of an internal linker peptide in connection with a self-activation process is unprecedented.

As the major portion of the core protein synthesized in $E$. coli is degraded due to the proteolytic action of the processed clostripain, it is tempting to speculate that conformational parameters play a crucial role in the maturation pathway. We cannot exclude the possibility that other factors of the in vitro system, namely the presence of antioxidants and urea, could affect the amount of maturation-competent core protein. As native clostripain is prone to inactivation by oxidation of the catalytic active site cysteine residue (Gilles et al., 1979), it is conceivable, that only core protein molecules with their active site residues existing in a non-oxidized state are able to perform self-activation.

Using the authentic $C$. histolyticum signal peptide, export of the pro-enzyme to the $E$. coli periplasm could not be 
achieved. The absence of translocation of the hybrid protein carrying the E. coli OmpA signal peptide suggests that the translocation block is probably due to protein aggregation effects and not provoked by a defective signal peptide. In contrast, the $C$. bistolyticum signal peptide of the clostripain precursor seems to be efficiently recognized by the $B$. subtilis secretion machinery since high amounts of active clostripain could be detected in supernatants of BR151 transformants harbouring pHM7-10B. This is not surprising as the clostripain signal peptide exhibits some characteristics of bacilli signal peptides, i.e. they are longer than signal peptides of Gram-negative bacteria and carry more positively charged residues at their ultimate N-termini (Simonen \& Palva, 1993).

In addition, trace amounts of intracellularly located clostripain precursor molecules (either prepro-enzyme or core protein) were also detectable in B. subtilis transformants early after induction. Western blot analysis did not reveal the presence of mature enzyme in the cytoplasm. Presumably, the intracellular environment does not allow the maturation of precursors which are degraded by the cellular protein turnover, when they cannot be delivered to the growth medium.

In culture supernatants of BR151 cells carrying pHM7$10 \mathrm{~B}$ both clostripain activity and an antigen exhibiting the same molecular mass as the clostripain heavy chain were detected without the requirement for an in vitro activation step. In the presence of TLCK, an antigenic protein with a molecular mass corresponding to the clostripain proenzyme is detectable instead. As a portion of the core peptide synthesized in E. coli was shown to be capable of auto-maturation, we assume that the clostripain precursor, upon its secretion by the heterologous host $B$. subtilis, is rapidly converted to mature, active clostripain. The participation of Bacillus proteases in this process was shown to be unlikely, as neither induced BR151 cells carrying PREP9 nor culture supernatants thereof were able to provoke the maturation of purified core peptide synthesized in E. coli. However, the fate of the clostripain pro-peptide remains speculative, but it is currently under investigation with the aid of protein sequence determinations.

\section{ACKNOWLEDGEMENTS}

We thank Dr D. Stueber, Hoffmann-La Roche, Basel, for kindly providing plasmid pREP9, Heike Masannek for skilled technical assistance, and Hans-Georg Sarx and Diter von Wettstein for continuous encouragement. This work was supported by Bundesministerium für Forschung und Technologie (BEO 210319021).

\section{REFERENCES}

Bradford, M. (1976). A rapid and sensitive method for quantification of microgram quantities of protein utilizing the principle of protein-dye binding. Anal Biochem 72, 248-254.

Bullock, W. O., Fernandez, J. M. \& Short, J. M. (1987). XL1-Blue: a high efficiency plasmid transforming recA Escberichia coli strain with $\beta$-galacrosidase selection. Biotecbniques 5, 376-379.

Canosi, U., Morelli, G. \& Trautner, T. A. (1978). The relationship between molecular structure and transformation efficiency of some
S. aureus plasmids isolated from B. subtilis. Mol \& Gen Genet 166, 259-267.

Dargatz, H., Diefenthal, T., Witte, V., Reipen, G. \& von Wettstein, D. (1993). The heterodimeric protease clostripain from Clostridium bistolyticum is encoded by a single gene. Mol \& Gen Genet 240, 140-145.

Dubnau, D. \& Davidoff-Abelsen, R. (1971). Fate of transforming DNA following uptake by competent Bacillus subtilis. I. Formation and properties of the donor-recipient complex. J Mol Biol 56, 209-221.

Fortier, G. \& McKenzie, S. L. (1986a). Peptide bond synthesis by clostridiopeptidase B. Biotechnol Lett 8, 777-782.

Fortier, G. \& McKenzie, S. L. (1986b). Substrate- and stereospecificities in clostripain-catalysed peptide synthesis. Biotechnol Lett 8, 873-876.

Gilles, A. M. \& Keil, B. (1984). Evidence for an active-center cysteine in the SH-proteinase $\alpha$-clostripain through use of $N$-tosylL-lysine chloromethyl ketone. FFBS Lett 173, 58-62.

Gilles, A. M., Imhoff, J. M. \& Keil, B. (1979). $\alpha$-Clostripain : chemical characterization, activity, and thiol content of the highly active form of clostripain. J Biol Chem 254, 14621468.

Gilles, A. M., De Wolf, A. \& Keil, B. (1983). Amino-acid sequences of the active-site sulfhydryl peptide and other thiol peptides from the cysteine proteinase $\alpha$-clostripain. Eur J Biochem 130, 473-479.

Hardy, K. G. (1988). Bacillus cloning methods. In DNA Cloning, Vol. II, pp. 1-17. Edited by D. M. Glover. Oxford: IRL press.

Hopp, T. P., Prickett, K. S., Price, V. L., Libby, R. T., March, C. J., Cerretti, D. P., Urdal, D. L. \& Conlon, P. J. (1988). A short polypeptide marker sequence useful for recombinant protein identification and purification. Biotechnology 6, 1204-1210.

Kocholaty, W., Weil, L. \& Smith, L. (1938). Proteinase secretion and growth of Clostridium histolyticum. Biochem J 32, 16851690.

Kyhse-Anderson, J. (1984). Electroblotting of multiple gels: a simple apparatus without buffer tank for rapid transfer of proteins from polyacrylamide to nitrocellulose. J Biochem Biophys Methods 10, 203-213.

Laemmli, U. K. (1970). Cleavage of structural proteins during the assembly of the head of bacteriophage T4. Nature 227, 680-685.

LeGrice, S. F. J. (1990). Regulated promoter for high-level expression of heterologous genes in Bacillus subtilis. Metbods Enzymol 185, 201-214

Lowe, P. A., Rhind, S. K., Sugrue, R. \& Marston, F. A. O. (1987). Protein purification. Micro Macro-UCLA Symposium. Mol Cell Biol 68, 429.

Meiwes, J., Müller, W., Grabley, S. \& Schudok, M. (1991). Clostripain: production and use for peptide synthesis. Biomed Biochim Acta 50, 80-83.

Neu, H. C. \& Heppel, L. A. (1965). The release of enzymes from Eschericbia coli by osmotic shock and during the formation of spheroplasts. J Biocbem 240, 3685-3692.

Ogle, J. D. \& Tytell, A. A. (1953). The activity of Clostridium bistolyticum proteinase on synthetic substrates. Arch Biochem Biopbys 42, 327-336.

Ohara, T., Makino, K., Shinagawa, H., Nakata, A., Norioka, S. \& Sakiyama, F. (1989). Cloning, nucleotide sequence, and expression of Achromobacter protease I gene. J Biol Chem 264, 20625-20631.

Ohta, Y., Hojo, H., Aimoto, S., Kobayashi, T., Zhu, X., Jordan, F. \& Inouye, M. (1991). Pro-peptide as an intermolecular chaperone: renaturation of denatured subtilisin $E$ with a synthetic pro-peptide. Mol Microbiol 5, 1507-1510.

Peschke, U., Beuck, V., Bujard, H., Gentz, R. \& LeGrice, S. (1985). 
Efficient utilization of Escherichia coli transcriptional signals in Bacillus subtilis. J Mol Biol 186, 547-555.

Sambrook, J., Fritsch, E. F. \& Maniatis, T. (1989). Molecular Cloning: A Laboratory Manual. Cold Spring Harbor, NY: Cold Spring Harbor Laboratory.

Silen, J. L., Frank, D., Fujishige، A., Bone, R. \& Agard, D. A. (1989). Analysis of prepro- $\alpha$-lytic protease expression in Escherichia coli reveals that the pro-region is required for activity. $J$ Bacteriol 171, 1320-1325.

Simonen, M. \& Palva, I. (1993). Protein secretion in Bacillus species. Microbiol Rev 57, 109-137.

Sizmann, D., Keilmann, C. \& Böck, A. (1990). Primary structure requirements for the maturation in vivo of penicillin acylase from Escherichia coli ATCC 11105. Eur J Biochem 192, 143-151.

Studier, F. W. (1973). Analysis of bacteriophage T7 early RNAs and proteins on slab gels. $J$ Mol Biol 79, 237-248.

Stueber, D., Ibrahimi, I., Cutler, D., Dobberstein, B. \& Bujard, H. (1984). A novel in vitro transcription-translation system: accurate and efficient synthesis of single proteins from cloned DNA sequences. EMBO J 3, 3143-3148.
Terada, I., Kwon, S. T., Miyata, Y., Matsuzawa, H. \& Ohta, T. (1990). Unique precursor structure of an extracellular protease, aqualysin $\mathrm{I}$, with $\mathrm{NH}_{2}$ - and $\mathrm{COOH}$-terminal pro-sequences and its processing in Eschericbia coli. J Biol Chem 265, 6576-6581.

Towbin, H., Staehlin, R. \& Gordon, J. (1979). Electrophoretic transfer of proteins from polyacrylamide gels to nitrocellulose sheets: procedure and applications. Proc Natl Acad Sci US A 76, 4350-4355.

Wandersman, C. (1989). Secretion, processing and activation of bacterial extracellular proteases. Mol Microbiol 3, 1825-1831.

Wu, X. C., Lee, W., Tran, L. \& Wong, S. L. (1991). Engineering a Bacillus subtilis expression-secretion system with a strain deficient in six extracellular proteases. J Bacteriol 173, 4952-4958.

Yamagata, H., Nakahama, K., Suzuki, Y., Kakinuma, A., Tsukagoshi, N. \& Udaka, S. (1989). Use of Bacillus brevis for efficient synthesis and secretion of human epidermal growth factor. Proc Natl Acad Sci US A 86, 3589-3593.

Received 30 July 1993; revised 16 November 1993; accepted 2 December 1993. 